\title{
Pengenalan Kearsipan dan Pelatihan Arsip Digital untuk Pustakawan dan Tata Usaha Sekolah Se Kota Madya Pekanbaru
}

\author{
Rismayeti*, Evizariza, Triono Dul Hakim, Vita Amelia \\ Fakultas Ilmu Budaya, Universitas Lancang Kuning \\ *Email : rismayeti@gmail.com
}

\begin{abstract}
This service activity aims to provide understanding and training to librarians and school administrators throughout Pekanbaru City. Associated with Archive and Archive issues. The common problem of partners is that the discovery of several librarians and school administrators in Pekanbaru City Middle City does not understand the importance of managing and maintaining records properly in accordance with applicable provisions such as Law no. 43 of 2009 concerning archiving The target of the results of this community service activity is to provide increased understanding and training for Librarians and Administration on how to manage archives and implement digital archive management in libraries and in schools. activities that can be carried out in the school library and provide an understanding of the importance of maintenance (archive preservation). The output produced according to this activity plan for proposers is in the form of scientific articles and enriching teaching materials. The method of implementing activities is counseling. The delivery of material is carried out by lecturers who are members of the team that propose community service activities.
\end{abstract}

Keywords: Archives, Digital Archives, Librarians

\begin{abstract}
Abstrak
Kegiatan pengabdian ini bertujuan untuk memberikan pemahaman dan pelatihan kepada pustakawan dan Tata Usaha Sekolah se Kota Madya Pekanbaru. Terkait dengan permasalahan Arsip dan Kearsipan. Permasalahan umum pihak mitra ialah Masih ditemukannya beberapa pustakawan dan Tata Usaha sekolah di Kota Madya Pekanbaru belum memahami tentang pentingnya mengelola dan memelihara arsip dengan baik sesuai dengan ketentuan yang berlaku seperti UU No. 43 tahun 2009 tentang kearsipan Target dari hasil kegiatan pengabdian kepada masyarakat ini adalah memberikan peningkatan pemahaman dan pelatihan Pustakawan dan Tata Usaha tentang bagaimana mengelola arsip dan menerapkan pengelolaan arsip digital di perpustakaan maupun disekolah. kegiatan-kegiatan yang dapat dilaksanakan di perpustakaan sekolah serta memberikan pemahan terhadap pentingnya tentang pemeliharaan (preservasi arsip). Luaran yang dihasilkan sesuai rencana kegiatan ini bagi pengusul berupa artikel ilmiah dan memperkaya bahan ajar. Adapun metode pelaksanaan kegiatan ialah penyuluhan. Penyampaian materi dilakukan oleh dosen yang tergabung dalam tim pengusul kegiatan pengabdian kepada masyarakat.
\end{abstract}

Kata kunci: Kearsipan, Arsip Digital, Pustakawan 


\section{Pendahuluan}

Salah satu indikator keberhasilan suatu sekolah dalam rangka peningkatan akreditasi sekolah adalah dokumen dan arsip yang tersedia dan tertata dengan baik. Sesuai dengan peraturan pemerintah yakni UU N0. 43 tahun 2009, Negara menyelenggarakan pelindungan dan penyelamatan arsip sebagaimana dimaksud dalam Pasal 7 huruf g, baik terhadap arsip yang keberadaanya di dalam maupun di luar wilayah Negara Kesatuan Republik Indonesia sebagai bahan pertanggungjawaban setiap aspek kehidupan berbangsa dan bernegara untuk kepentingan negara, pemerintahan, pelayanan publik, dan kesejahteraan rakyat.

Dalam proses akreditas sekolah ada beberapa dokumen/arsip yang harus disiapkan, dokumen tersebut meliputi 8 standar pendidikan seperti : 1) standar isi, 2) standar proses, 3) standar kompetensi lulusan, 4) standar pendidik dan pendidikan, 5) standar sarana dan prasarana, 6) standar pengelolaan, 7) standar pembiayaan, 8) standar penilaian.

Sesuai dengan ketetapan Badan Akreditasi Nasional Sekolah dan Ma drasah (BANSM) tahun 2018 telah menetapkan akreditasi sekolah dengan masa berlakunya adalah 4 tahun, selama 4 tahun tersebut pustakawan ataupun tata usaha sekolah harus menyiapkan dan meng-arsipkan item-item standar penilaian yang sudah ditetapkan. Hasil penilaian ini sangat tergantung kepada ketersediaan arsip atau dokumen 4 tahun kebelakang. Hal ini tidak mudah dilakukan seandainya pustakawan atau Tata usaha sekolah yang telah ditugaskan untuk mengelola arsip tidak sungguh-sungguh dan tidak punya kemampuan dalam hal pengelolaan arsip.

\section{Pedekatan Pelaksanaan Program Metode Pelaksanaan}

Adapun metode pelaksanaan kegiatan ialah memberikan pemahaman tentang pengelolaan dan penyimpanan arsip secara manual maupun digital. Penyampaian materi dilakukan oleh dosen yang tergabung dalam tim pengusul kegiatan pengabdian kepada masyarakat. Selain itu kegiatan dalam rangka pengabdian kepada masyarakat menggunakan dua metode, yaitu 1) Ceramah atau penyuluhan. Dalam metode ini penceramah atau penyuluh menyampaikan materi tentang Pengenalan Kearsipan Dan Pelatiahan Arsip Digital. Dalam kesempatan itu peserta dibebaskan untuk bertanya jawab dengan pemberi materi . Rincian dari metode ini ialah pemaparan mengenai bagaimana mengelola arsip dengan system digital 2) Dialog interaktif, dalam hal ini peserta diposisikan sebagai subjek yang dapat memberikan ulasan terkait dengan problematika dalam pengelolaan arsip. Dialog ini sebagai curah pendapat (brainstorming) dari peserta untuk memperoleh masukan berupa persoalan, aspirasi, usulan, gagasan dan solusi. 3) Penyebaran kuisioner sebelum dan sesudah dilaksanakannya penyuluhan (kuisioner pretest dan posttest). Tujuan dilaksanakannya penyebaran kuisioner ini adalah untuk mendapatkan perbandingan pengetahuan dan wawasan peserta tentang Pengelolaan Arsip. 


\section{Prosedur Kerja}

Prosedur kerja yang akan dilaksanakan dengan beberapa tahap, yaitu Pertama, tahap persiapan. Persiapan ini difokuskan dengan menyiapkan semua peralatan yang dibutuhkan untuk melaksanan kegiatan ini, studi literatur dan melakukan koordinasi dengan organisasi terkait untuk melakukan kegiatan.

Kedua, kunjungan ke lokasi untuk menentukan tempat (lokasi) kegiatan pelatihan.

Ketiga, perancangan materi Pengenalan Kearsipan Dan Pelatiahan Arsip Digital Untuk Pustakawan dan Tata Usaha Sekolah Se Kota Madya Pekanbaru dengan mempersiapkan materi yang akan ditampilkan dalam kegiatan. Modul diperbanyak sejumlah peserta yang terlibat dalam kegiatan.

Keempat, pelaksanaan dilakukan oleh tim pelaksana Pengabdian dari Universitas Lancang Kuning. Adapun yang menjadi ukuran keberhasilan kegiatan ini, yakni 1) Terwujudnya kerja sama antara pelaksana kegiatan dengan pihak Forum Perpustakaan Perguruan Tinggi Riau, 2) Jumlah peserta yang hadir minimal 50\% dari undangan, 3) Adanya interaksi dua arah dalam kegiatan antara pembicara dan peserta, 4) Meningkatnya pemahaman peserta terkait dengan materi yang disampaikannya, 5) Peningkatan pemahaman peserta kegiatan diukur dengan penyebaran kuesioner sebelum dan sesudah kegiatan.

\section{Pelaksanaan Program}

Kegiatan ini dilaksanakan pada tanggal 29 Januari 2019 di Aula Perpustakaan Unilak, yang diikuti oleh 38 orang peserta terdiri dari pustakawan dan tata usaha sekolah yang ada di kota Madya Pekanbaru Berdasarkan kegiatan yang telah dilaksanakan, beberapa hal yang telah diperoleh.

Tahap pertama, peserta dibagikan kuesioner pretest untuk diisi peserta, setelah itu instruktur (narasumber) menjelaskan tentang bagaimana tentang pengelolaan kearsipan dan arsip digital.

Tahap kedua, peserta diajak untuk memahami materi yang disampaikan dan dipresentasikan oleh Narasumber (Rismayeti, M.IP dan Triono Dul Hakim, M.IP), kemudian pada sesi ini juga dibuka sesi tanya jawab, bagi mereka masih belum memahami tentang pengelolaan kerarsipan dan arsip digital. narasumber menjawab pertanyaan - pertanyaan yang dilontarkan oleh peserta. Rata-rata peserta sudah memahami arsip secara manual atau konvensional, tetapi sebagian besar peserta belum mengerti mengelola arsip secara digital.

Pada tahap terakhir, setelah peserta diberikan pembekalan tentang arsip digital dan pengkodean arsip, mereka bisa memahami pendigitalan arsip dan pengkodean arsip tersebut. 


\section{Gambar 1 Pelaksanaan Pengabdian}

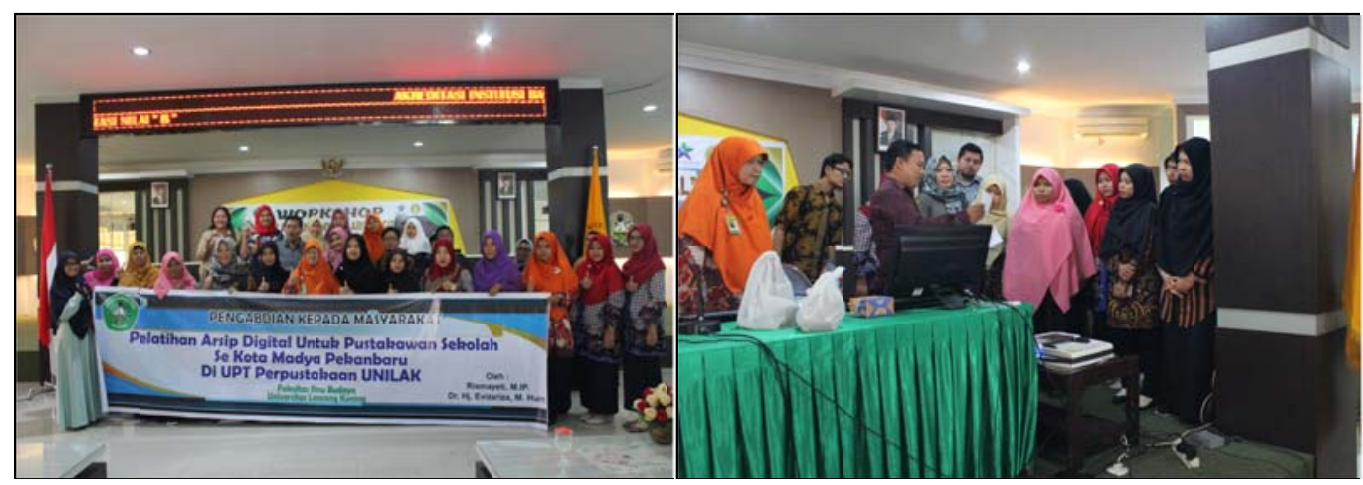

\section{Luaran yang Dicapai}

Evaluasi, ini diperoleh dari hasil olahan kuesioner yang diberikan kepada peserta sebanyak 38 orang sebelum dan sesudah pelatihan dilakukan. Kemudian dari jawaban kuesioner yang diberikan akan kelihatan perbandingan pengetahuan peserta sebelum dan sesudah mengikuti pelatihan. Dari penyebaran kuesioner tersebut dapat diketahui bagaimana pemahaman peserta terhadap materi yang diberikan selama pelatihan. Untuk lebih jelasnya dapat dilihat hasil rekapitulasi jawaban responden sebagai berikut :

Tabel 1. Hasil Rekapitulasi Kuesioner Pretest

\begin{tabular}{|c|c|c|c|c|}
\hline No & Item Pertanyaan & Pernah & $\begin{array}{l}\text { Tidak } \\
\text { Pernah }\end{array}$ & Total \\
\hline 1. & $\begin{array}{l}\text { Apakah anda pernah mendengar tentang } \\
\text { pengelolaan arsip digital }\end{array}$ & 38 & 0 & 38 \\
\hline 2 & $\begin{array}{l}\text { Apakah anda pernah mengikuti pelatihan } \\
\text { pengelolaan arsip digital }\end{array}$ & 8 & 30 & 38 \\
\hline 3 & $\begin{array}{l}\text { Apakah anda pernah mengelola arsip } \\
\text { secara digital }\end{array}$ & 0 & 38 & 38 \\
\hline 4 & $\begin{array}{l}\text { Apakah anda pernah melakukan } \\
\text { klasifikasi arsip digital }\end{array}$ & 0 & 38 & 38 \\
\hline 5 & $\begin{array}{l}\text { Setelah mengikuti pelatihan ini, saya } \\
\text { memahami perangkat pendigitalan arsip }\end{array}$ & 0 & 38 & 38 \\
\hline 6 & $\begin{array}{l}\text { Setelah mengikuti pelatihan ini, saya } \\
\text { memahami pengelolaan arsip digital }\end{array}$ & 0 & 38 & 38 \\
\hline 7 & $\begin{array}{l}\text { Setelah mengikuti pelatihan ini, saya akan } \\
\text { mengelola arsip ditempat bekerja dengan } \\
\text { cara pengelolaan arsip digital }\end{array}$ & 0 & 38 & 38 \\
\hline 8 & $\begin{array}{l}\text { Setelah mengikuti pelatihan ini, saya } \\
\text { mampu mengelola arsip digital }\end{array}$ & 0 & 38 & 38 \\
\hline 9 & Apakah pelatihan ini bermanfaat & 38 & 0 & 38 \\
\hline
\end{tabular}

Berdasarkan tabel di atas dapat disimpulkan bahwa dari 38 peserta pernah mendengar tentang pengelolaan arsip digital dan 8 orang yang pernah mengikuti 
pelatihan pengelolaan mendengar tentang pengelolaan arsip digital. Untuk pertanyaan nomor $3-8$ peserta benar-benar belum pernah dan belum memahami tentang arsip digital. Untuk pertanyaan terakhir $100 \%$ peserta menyatakan pelatihan ini bermanfaat.

\section{Tabel 2. Hasil Rekapitulasi Kuesioner Posttest}

\begin{tabular}{|c|l|c|c|c|}
\hline No & \multicolumn{1}{|c|}{ Item Pertanyaan } & Pernah & $\begin{array}{c}\text { Tidak } \\
\text { Pernah }\end{array}$ & Total \\
\hline 1 & $\begin{array}{l}\text { Apakah anda pernah mendengar tentang } \\
\text { pengelolaan arsip digital }\end{array}$ & 38 & 0 & 38 \\
\hline 2 & $\begin{array}{l}\text { Apakah anda pernah mengikuti pelatihan } \\
\text { pengelolaan arsip digital }\end{array}$ & 38 & 0 & 38 \\
\hline 3 & $\begin{array}{l}\text { Apakah anda pernah mengelola arsip } \\
\text { secara digital }\end{array}$ & 0 & 38 & 38 \\
\hline 4 & $\begin{array}{l}\text { Apakah anda pernah melakukan } \\
\text { klasifikasi arsip digital }\end{array}$ & 0 & 38 & 38 \\
\hline 5 & $\begin{array}{l}\text { Setelah mengikuti pelatihan ini, saya } \\
\text { memahami perangkat pendigitalan arsip }\end{array}$ & 38 & 0 & 38 \\
\hline 6 & $\begin{array}{l}\text { Setelah mengikuti pelatihan ini, saya } \\
\text { memahami pengelolaan arsip digital }\end{array}$ & 38 & 0 & 38 \\
\hline 7 & $\begin{array}{l}\text { Setelah mengikuti pelatihan ini, saya akan } \\
\text { mengelola arsip ditempat bekerja dengan } \\
\text { cara pengelolaan arsip digital }\end{array}$ & 20 & 18 & 38 \\
\hline 8 & $\begin{array}{l}\text { Setelah mengikuti pelatihan ini, saya } \\
\text { mampu mengelola arsip digital }\end{array}$ & 20 & 18 & 38 \\
\hline 9 & \begin{tabular}{l} 
Apakah pelatihan ini bermanfaat \\
\hline
\end{tabular}
\end{tabular}

\section{Refleksi Capaian Program}

Dari hasil posttest untuk 38 peserta (100\%) peserta pernah mendengar dan sekaligus telah mengikuti pelatihan ini. Untuk pengelolaan dan pengklasifikasian arsip digital belum pernah mereka lakukan di tempat bekerja. Setelah mengikuti pelatihan ini $100 \%$ mereka perangkat dan pengelolaan arsip digital. Untuk pertanyaan poin 7 tentang penerapan aplikasi ini hanya sekitar $50 \%$ saja yang akan menerapkan di kantornya, setelah ditanya mereka menjawab terkendala dengan pengadaan sarana dan prasarananya. Untuk pertanyaan terakhir $100 \%$ mereka menyatakan pelatihan ini sangat bermanfaat.

\section{Penutup}

Pelatihan ini bermanfaat bagi peserta baik sebagai pustakawan maupun tata usaha sekolah sebagai pengelola arsip dan dokumen di perpustakaan ataupun sekolah terbukti dengan hasil pretest dan posttest menunjukkan $100 \%$ mereka memahami perangkat pendigitalan dan pengelolaan arsip digital, dan $50 \%$ mereka mampu dan akan mengelola arsip digital ditempat mereka bekerja, di sini terlihat ada peningkatan setelah diadakan pelatihan. Pelatihan ini sangat bermanfaat sekali bagi sekolah dalam 
rangka penyiapan arsip akreditasi sekolah yang harus mempersiapkan dokumen empat tahun ke belakang. Berdasarkan ini pelatihan kita lakukan untuk pustakawan dan tata usaha sekolah agar bisa menyiapkan arsip sesuai dengan tuntutan akreditasi sekolah.

Setelah pelatihan ini dilaksanakan diharapkan kepada peserta dapat mempraktikkan atau menggunakan sistem klasifikasi arsip dan arsip digital di sekolah masing-masing.

\section{Daftar Pustaka}

Amsyah, Zulkifli, 1996, Manajemen Kearsipan, Jakarta: Gramedia Pustaka Utama.

Barthos Basir. 1997, Manajemen Kearsipan Untuk Lembaga Negara, Swasta dan Perguruan Tinggi, Jakarta : Bumi Aksara.

Bafadal, Ibrahim, 2005, Pengelolaan Perpustakaan Sekolah, Bumi Aksara, Jakarta

Dian Sinaga, 2011, Mengelola Perpustakaan Sekolah, Bejana, Bandung, Martoatmojo, 1999, Pelayanan Bahan Pustaka, Universitas Terbuka, Jakarta

Permen Dalam Negeri No. 78 tahun 2012 tentang Pengelolaan Kearsipan Daerah, Kabupaten dan Kota.

Sutarno NS, 2006, Manajemen Perustakaan: Suatu Pendekatan Praktis, Sagung Seto, Jakarta

Sugiarto Agus, 2010, S.Pd., M.M., Teguh Wahyono, S.Kom.M.Cs. Manajemen Kearsipan Moderen, Yogyakarta: Gava Media.

Sulistyo-Basuki.1996, Pengantar Kearsipan, Jakarta : UT.

, 2010, Administrasi Arsip Sebuah Pengantar Memahami Arsip mulai dari prinsip sampai ke profesi, Hingga Penerimaan sampai ke Jasa Kearsipan. Jakarta.

Undang-Undang Republik Indonesia Nomor 43 Tahun 2009, Tentang Kearsipan.

Permen Dalam Negeri No. 78 tahun 2012 tentang Pengelolaan Kearsipan Daerah, Kabupaten dan Kota.

Wursanto, 1991, Kearsipan 1 dan 2, Yogyakarta : Kanisius.

UNESCO. (2003). Charter on the preservation of the digital heritage. Paris: UNESCO.

Perundangan-undangan:

Undang-Undang Dasar 1945 Amandemen Ke-IV

Undang-Undang Nomor 11 Tahun 2010 tentang Cagar Budaya. 